\title{
Small-sized companies' earnings management: evidence from Italy
}

\author{
Simone Poli \\ Department of Management, Faculty of Economics, Università Politecnica delle Marche \\ Piazzale R. Martelli n. 8, Ancona 60121, Italy \\ Tel: +39-071-2207258Ｅ-mail: s.poli@univpm.it
}

Received: August 28, 2013 Accepted: October 01, 2013 DOI: 10.5296/ijafr.v3i2.4191

\begin{abstract}
This study explores the earnings management practices of small-sized Italian companies. Adopting the earnings distribution approach, it finds that these companies are likely to manage their earnings to achieve two earnings level targets. On the one hand, they manage their earnings to report slightly positive earnings. Those with negative earnings manage them upward to be above the zero threshold. Those with positive earnings manage them downward to bring them close to zero. On the other hand, they manage their earnings to minimize earnings changes. The main implication of the findings of this study is that the small-sized Italian companies' earnings are not unconditionally informative regarding their performance. In other words, they are of poor quality. As a result, they should be interpreted with caution by those who use financial statement information. This study mainly enriches the literature on earnings management in two ways. Firstly, it provides evidence on small-sized companies' earnings management practices which are very little explored in literature. Secondly, it provides additional evidence on the earnings management practices undertaken in the Italian setting, and so in countries which are characterized by a code law system and a close alignment between accounting and tax systems.
\end{abstract}

Keywords: Earnings management, Earnings distribution approach, Loss avoidance, Earnings minimization, Earnings decrease avoidance, Earnings smoothing, Small-sized companies, Italy 


\section{MInstitute ${ }^{\text {Macrothink }}$}

International Journal of Accounting and Financial Reporting

ISSN 2162-3082

2013, Vol. 3, No. 2

\section{Introduction}

Although earnings management has been extensively investigated for a long time in the accounting and finance literature (e.g. Dechow and Skinner, 2000; Dechow et al., 2010; Fields et al., 2001; Hall et al., 2013; Healy and Wahlen, 1999; McNichols, 2000; Schipper, 1989; Verbruggen et al., 2008), there are still important aspects which remain little explored, such as the earnings management practices of small companies (interesting exceptions are, for example, Marques et al., 2011 and Mörec, 2013).

This could be due to two factors. On the one hand, small companies carry little weight in those countries (English-speaking ones) where most of the studies have explored earnings management practices. On the other hand, to have the necessary data for the survey is more problematic for small companies than for large companies.

However, small companies represent the majority of the companies in several countries, especially European ones. In addition, it is widely believed that small companies are very likely to practice earnings management because they do not have those restrictions which limit the large listed and/or unlisted companies. However, this has not yet been demonstrated sufficiently. Therefore, the exploration of earnings management practiced by small companies has great relevance.

Our study aims to enrich the understanding of small-sized companies' earnings management practices, exploring those undertaken in the Italian setting. Specifically, it intends to verify whether small-sized Italian companies are likely to manage earnings to achieve certain earnings levels.

Focusing on the Italian setting, moreover, our study enriches the understanding of earnings management practices in countries which are characterized by a code law system and a close alignment between accounting and tax systems, which are little explored in literature.

Our study is not the first one to explore the earnings management practices of Italian companies. However, it is the first one which focuses on small-sized Italian companies. Previous studies have explored the large Italian listed and/or unlisted companies (Coppens and Peek, 2005; Burgstahler et al., 2006; Poli, 2013; Prencipe, Markarian and Pozza, 2008).

From a methodological standpoint, we adopt the earnings distribution approach, according to which the presence of discontinuities in the companies' frequency distribution of earnings is the signal of earnings management practices undertaken to achieve certain earnings level targets (e.g. Burgstahler and Dichev, 1997; Degeorge et al., 1999). We adopt this approach for two main reasons. One, it is particularly useful when, as in our study, the research aim is to detect the frequency of earnings management practices since it identifies the context in which a large number of companies appears to have managed earnings (e.g. Healy and Wahlen, 1999; McNichols, 2000; Sun and Rath, 2010). Two, its application does not require information which would not be available for small companies, as required for the application of other approaches.

Our study proceeds as follows. Section 2 briefly reviews the literature and develops the 
research hypotheses. Section 3 introduces the research method and the sample selection. Section 4 shows and discusses the empirical results. Section 5 summarizes the main findings and contributions to literature.

\section{Literature review and development of the hypothesis}

Companies may manage their earnings to achieve certain earnings levels. When this happens, according to the earnings distribution approach (e.g. Burgstahler and Dichev, 1997; Degeorge et al., 1999), the companies' frequency distribution of earnings shows discontinuity around the earnings level targets.

If earnings are not managed to achieve certain earnings levels, the frequency distribution of earnings does not show discontinuity (it is relatively smooth). It is expected that the number of companies that achieve results lower than a given level to a certain extent and the number of companies that achieve results higher than that given level to the same extent are not significantly different.

Conversely, if earnings are managed to achieve certain earnings levels, the frequency distribution of earnings shows discontinuity in correspondence with such earnings levels. Discontinuity manifests itself with significantly fewer observations than expected just below the earnings level targets and significantly more observations than expected just above the earnings level targets.

Thus, according to the earnings distribution approach, the occurrence of discontinuity in the frequency distribution of earnings is evidence of earnings management practices.

Previous studies adopting this approach have documented the fact that companies manage earnings to achieve different earnings level targets.

Companies mainly manage earnings to avoid losses (e.g. Baber and Kang, 2002; Beatty, Ke and Petroni, 2002; Brown and Caylor, 2004; Burgstahler et al., 2006; Collins, Pincus and Xie, 1999; Coppens and Peek, 2005; Daske et al., 2006; Easton, 1999; Hamdi and Zarai, 2012; Hayn, 1995; Holland and Ramsay, 2003; Jacob and Jorgensen, 2007; Kerstein and Rai, 2007; Phillips et al., 2004; Revsine et al., 2009). In this case, the companies' frequency distribution of earnings shows a discontinuity between the first negative earnings interval to the left of zero (which is significantly under-represented) and the first positive earnings interval to the right of zero (which is significantly over-represented). This practice has been documented both in public (listed) companies and in private (unlisted) companies in all the countries in which it has been explored.

Companies manage earnings to minimize positive earnings (e.g. Marques et al., 2011; Poli, 2013). This is the result of two opposite earnings management practices. On the one hand, companies manage earnings to avoid losses, as in the previous case. On the other hand, companies with positive earnings manage them downward to minimize earnings. This is evidenced by the presence of a discontinuity between the first positive earnings interval (which is over-represented) and the second positive earnings interval (which is under-represented) to the right of zero. As a result, companies tend to report slightly positive 


\section{MInstitute Mach $^{m}$}

International Journal of Accounting and Financial Reporting ISSN 2162-3082 2013, Vol. 3, No. 2

earnings. The minimization of positive earnings has been documented in certain countries where there is a close alignment between accounting and tax systems (Belgium and Italy). The best explanation for this is the presence of fiscal incentives. Fiscal incentives encourage companies with positive earnings to manage them downward to bring them close to zero, thus minimizing tax payments, on one side, and encourage those with negative earnings to manage them upward to overcome the zero threshold, thus decreasing the probability of tax audits, on the other (Herrmann and Inoue, 1996).

Companies manage earnings to avoid earnings decreases (e.g. Burgstahler and Dichev, 1997; Degeorge et al., 1999; Coppens and Peek, 2005). In this case, the companies' frequency distribution of earnings changes shows a discontinuity between the first negative earnings change interval to the left of zero (which is significantly under-represented) and the first positive earnings change interval to the right of zero (which is significantly over-represented). According to Coppens and Peek (2005), with reference to European countries, public companies manage earnings to avoid earnings decreases only in countries where there is no alignment between accounting and tax systems and where the capital market is well developed (The Netherlands and the U.K.). Conversely, large private and public companies do not manage earnings to avoid earnings decreases in the other observed countries (Belgium, Denmark, France, Germany, Italy and Spain).

Companies manage earnings to avoid large earnings changes (Coppens and Peek, 2005). Private companies (in Belgium and Italy) prefer small earnings changes to large earnings changes. This is indicative of earnings smoothing. In this case, the companies' frequency distribution of earnings changes shows two discontinuities: the first one between the second (which is under-represented) and the first (which is over-represented) negative earnings change intervals to the left of zero, the second one between the first (which is over-represented) and the second (which is under-represented) positive earnings change intervals to the right of zero.

Companies manage earnings to avoid missing analysts' earnings expectations (e.g. Degeorge et al., 1999). In this case, the companies' frequency distribution of forecast error for earnings per share shows a discontinuity between the first negative interval to the left of zero (which is significantly under-represented) and the first positive interval to the right of zero (which is significantly over-represented). This practice has been documented in American public (listed) companies.

Burgstahler et al. (2006) have analyzed the earnings management practices in European private and public companies, finding that these practices are more pervasive in the former. In addition, the authors have provided evidence that earnings management practices are more pervasive in countries with weaker legal systems and enforcement. This effect holds true for both private and public companies, confirming the central role played by enforcement mechanisms.

Some studies have found alternative explanations for the discontinuity in the frequency distribution of earnings around zero (e.g. Beaver et al., 2007; Dechow et al., 2003; Durtschi and Easton, 2005, 2009), which would imply that researchers should be cautious in finding 


\section{Macrothink}

International Journal of Accounting and Financial Reporting

ISSN 2162-3082 2013, Vol. 3, No. 2

the cause of such a discontinuity in earnings management practices. Conversely, earnings management remains the best explanation for the discontinuity around other benchmarks (Hall et al., 2013).

Taking into account the previous studies' findings we have summarized above, in order to explore the earnings management practices of small-sized Italian companies, we test the following hypotheses:

$\mathrm{H}_{1}$ : small-sized Italian companies manage earnings to avoid losses.

$\mathrm{H}_{2}$ : small-sized Italian companies manage earnings to minimize earnings.

$\mathrm{H}_{3}$ : small-sized Italian companies do not manage earnings to avoid earnings decreases.

$\mathrm{H}_{4}$ : small-sized Italian companies manage earnings to avoid great earnings changes.

\section{Research design and sample selection}

\subsection{The research method}

To test our research hypotheses, we adopt the earnings distribution approach as proposed by Burgstahler and Dichev (1997). According to it, the presence of discontinuity in the frequency distribution of earnings signals the existence of earnings management practices.

Once the frequency distribution of earnings has been constructed, a discontinuity emerges whether the number of the actual observations which falls in a given interval is significantly higher than the expected one and whether the number of the actual observations which falls in one or both of the immediately adjacent intervals is significantly lower than the expected one. The assumption is that the companies whose earnings would have had to fall in the under-represented interval have managed them to ensure that they fall in the over-represented interval.

To detect discontinuities, we use graphical and statistical analysis.

Firstly, we construct and explore the graphical representation of the frequency distribution of earnings and earnings changes. To do so, we use histograms in which the x-axis shows earnings and earnings change intervals and the $y$-axis shows frequencies, namely the numbers of the observations that fall in each earnings and earnings change interval.

The construction of the histograms requires the definition of earnings, earnings changes and interval amplitudes.

With reference to earnings, they are defined as follows:

$$
\mathrm{E}_{\mathrm{it}}=\frac{\mathrm{NI}_{\mathrm{it}}}{\mathrm{TA}_{\mathrm{it}-1}}
$$

where: $E_{i t}$ is the earnings reported by company $\mathrm{i}$ in financial year $\mathrm{t} ; \mathrm{NI}_{\mathrm{it}}$ is the net income reported by company $i$ in financial year $t$; $\mathrm{TA}_{\mathrm{it}-1}$ is the total assets of company $\mathrm{i}$ in financial year $\mathrm{t}-1$. 


\section{Macrothink}

International Journal of Accounting and Financial Reporting

ISSN 2162-3082

2013, Vol. 3, No. 2

The earnings which should be used represent a critical and debated issue in literature (e.g. Durtschi and Easton, 2005; Durtschi and Easton, 2009; Holland, 2004; McNichols, 2003). One of the more critical and debated issues refers to the deflator. The use of the total assets of the previous financial year reduces the problem of heteroscedasticity (e.g. Coppens and Peek, 2005; Gore et al., 2007; Marques et al., 2011). However, to ensure the robustness of the findings, the investigation was repeated using different deflators (shareholders' equity and sales) as well as the absolute values of earnings. The findings obtained were qualitatively similar to those that are shown.

With reference to earnings changes, they are defined as follows:

$\mathrm{EC}_{\mathrm{it}}=\frac{\mathrm{NI}_{\mathrm{it}}-\mathrm{NI}_{\mathrm{it}-1}}{\mathrm{TA}_{\mathrm{it}-2}}$

where: $\mathrm{EC}_{\mathrm{it}}$ is the earnings change reported by company $\mathrm{i}$ in financial year $\mathrm{t} ; \mathrm{NI}_{\mathrm{it}}$ is the net income reported by company $\mathrm{i}$ in financial year $\mathrm{t}$; $\mathrm{NI}_{\mathrm{it}-1}$ is the net income reported by company $\mathrm{i}$ in financial year $\mathrm{t}-1 ; \mathrm{TA}_{\mathrm{it}-2}$ is the total assets of company $\mathrm{i}$ in financial year $\mathrm{t}-2$.

With reference to earnings and earnings change interval amplitudes, we show the results referring to the interval amplitudes of 0.005 and 0.0025 , respectively. Further details are provided in the note to the figures below. This choice was made primarily to facilitate the comparison of our findings with those of previous studies. However, to ensure the robustness of the results, the investigation was repeated using different interval amplitudes (e.g. Scott, 1979; Silverman, 1986). The findings obtained were qualitatively similar to those that are shown.

Secondly, we estimate the statistical significance of the discontinuities which may emerge in the frequency distributions of earnings and earnings changes. To do so, we use the Burgstahler and Dichev's (1997) statistical test which is defined as follows:

$Z_{i}=\frac{n a_{i}-n e_{i}}{\sigma_{i}}=\frac{n_{i}-\frac{n_{i-1}+n_{i+1}}{2}}{\sqrt{N p_{i}\left(1-p_{i}\right)+\frac{N\left(p_{i-1}+p_{i+1}\right)\left(1-p_{i-1}-p_{i+1}\right)}{4}}}$

where: $\mathrm{Z}_{\mathrm{i}}$ is the statistical test, referring to interval $\mathrm{i}$, with approximately normal distribution (with mean zero and standard deviation one); $\mathrm{na}_{\mathrm{i}}$ is the actual number of observations which fall in interval $\mathrm{i} ; \mathrm{ne}_{\mathrm{i}}$ is the expected number of observations which fall in interval $\mathrm{i} ; \sigma_{\mathrm{i}}$ is the standard deviation of the differences between the actual and the expected numbers of observations which fall in interval $i ; n_{i}, n_{i-1}$ and $n_{i+1}$ are the actual numbers of observations which fall in intervals $i, i-1$ and $i+1$, respectively; $\mathrm{N}$ is the total number of observations; $\mathrm{p}_{\mathrm{i}}$, $\mathrm{p}_{\mathrm{i}-1}$ and $\mathrm{p}_{\mathrm{i}+1}$ are the portions of actual observations which fall in intervals $\mathrm{i}, \mathrm{i}-1$ and $\mathrm{i}+1$, respectively.

The statistical test is based on the assumption that the frequency distributions of earnings and 
earnings change levels are smooth under the null hypothesis of no earnings management practices. As suggested in Burgstahler and Dichev (1997), they are smooth if the expected number of observations which fall in an interval $\left(\mathrm{ne}_{\mathrm{i}}\right)$ is the average of the number of observations that fall in the two immediately adjacent intervals $\left(\mathrm{na}_{\mathrm{i}-1}\right.$ and $\left.n \mathrm{a}_{\mathrm{i}+1}\right)$.

Garrod et al. (2006) report that Burgstahler and Dichev's (1997) statistical test is not significantly affected by the choice referring to the amplitude of earnings and earnings change intervals.

\subsection{Sample selection and data}

We define small-sized companies as companies which employ fewer than 50 employees and whose annual turnover or annual balance sheet total does not exceed 10 million euros.

In doing so, our definition is inspired by, but not identical to, that provided by the European Commission's Recommendation 2003/361/CE. Compared to this one, we have used only the quantitative parameters, ignoring the qualitative ones, and we have included "micro" companies. In addition, the lack of data on the number of annual work units and the amount of turnover has led us to use proxies for such parameters. With reference to the first parameter, we have used the number of employees. With reference to the second parameter, we have used the first item of the income statement prepared according to Italian rules, namely "revenues from sales and services".

The sample of small-sized Italian companies used to test the research hypotheses was extracted (on 25th July 2013) from the "Analisi Informatizzata Delle Aziende" (AIDA) database supplied by Bureau van Dijk. The AIDA database provides financial statement data for a vast set of Italian private and public companies operating in sectors other than the financial one.

The companies included in the sample present the following features:

- they meet the abovementioned quantitative parameters (number of employees lower than 50 and revenues from sales and services not exceeding 10 million euros or annual balance sheet total not exceeding 10 million euros) for each year in the period 2003-2011;

- they operate in sectors other than the financial one;

- $\quad$ they are unlisted;

- they prepare (non-consolidated) financial statements adopting the Italian national accounting standards;

- their financial statement is available in the database for each year in the period 2003-2011.

The sample includes a total of 123176 firm-year observations for the analysis of earnings levels and a total of 107779 firm-year observations for the analysis of earnings change levels. Taking into account how earnings changes have been defined and that the amounts of total 
assets referring to 2002 are not available in the database, it was not possible to calculate the earnings changes relative to 2004. As a result, the second total number of observations is lower than the first one. Table 1 shows the main descriptive statistics referring to them.

Table 1. Descriptive statistics

\begin{tabular}{|c|c|c|c|c|c|c|c|c|c|}
\hline & 2011 & 2010 & 2009 & 2008 & 2007 & 2006 & 2005 & 2004 & Total \\
\hline Earnings (E) observations & 15397 & 15397 & 15397 & 15397 & 15397 & 15397 & 15397 & 15397 & 123176 \\
\hline mean & 0.01536 & 0.01857 & 0.01255 & 0.02438 & 0.02887 & 0.02528 & 0.02355 & 0.02515 & 0.02171 \\
\hline standard deviation & 0.05743 & 0.05548 & 0.05521 & 0.06057 & 0.05592 & 0.05391 & 0.05216 & 0.05726 & 0.05629 \\
\hline first quartile & -0.00341 & -0.00154 & -0.00782 & 0.00000 & 0.00135 & 0.00084 & 0.00081 & 0.00076 & 0.00021 \\
\hline second quartile (median) & 0.00606 & 0.00702 & 0.00516 & 0.01006 & 0.01354 & 0.01070 & 0.01018 & 0.01067 & 0.00896 \\
\hline third quartile & 0.03086 & 0.03405 & 0.02927 & 0.04281 & 0.04591 & 0.04084 & 0.03809 & 0.04080 & 0.03788 \\
\hline \multirow[t]{2}{*}{ Observations in positive earnings intervals } & 11026 & 11264 & 10430 & 11466 & 12339 & 12101 & 12095 & 12042 & 92763 \\
\hline & $71.61 \%$ & $73.16 \%$ & $67.74 \%$ & $74.47 \%$ & $80.14 \%$ & $78.59 \%$ & $78.55 \%$ & $78.21 \%$ & $75.31 \%$ \\
\hline Earnings change (EC) observations & 15397 & 15397 & 15397 & 15397 & 15397 & 15397 & 15397 & & 107779 \\
\hline mean & -0.00068 & 0.00734 & -0.01058 & -0.00177 & 0.00718 & 0.00465 & 0.00201 & & 0.00116 \\
\hline standard deviation & 0.04778 & 0.04686 & 0.05263 & 0.04793 & 0.04534 & 0.04595 & 0.04950 & & 0.04840 \\
\hline first quartile & -0.01540 & -0.01006 & -0.02900 & -0.01959 & -0.00936 & -0.01168 & -0.01427 & & -0.01527 \\
\hline second quartile (median) & -0.00023 & 0.00179 & -0.00312 & -0.00078 & 0.00261 & 0.00088 & 0.00036 & & 0.00026 \\
\hline third quartile & 0.01395 & 0.02091 & 0.01021 & 0.01423 & 0.02091 & 0.01722 & 0.01535 & & 0.01622 \\
\hline \multirow[t]{2}{*}{ Observations in positive earnings change intervals } & 7526 & 8647 & 6512 & 7312 & 8973 & 8264 & 7973 & & 55207 \\
\hline & $48.88 \%$ & $56.16 \%$ & $42.29 \%$ & $47.49 \%$ & $58.28 \%$ & $53.67 \%$ & $51.78 \%$ & & $51.22 \%$ \\
\hline
\end{tabular}

A few observations take on extreme values. So all the descriptive statistics shown in the table are calculated after eliminating the upper and the lower $1 \%$ of the observations for each year.

\section{Results and discussion}

\subsection{The earnings management practices of small-sized Italian companies}

Figure 1 shows the frequency distribution of earnings of the small-sized Italian companies included in the sample. It presents a trend that is convex both to the left and to the right of zero, a peak of observations in interval 1 , a discontinuity both to the left and to the right of interval 1.

Table 2 shows that there is a statistically significant difference between actual and expected observations in five earnings intervals $(-1,1,2,3$ and 4). Interval 1 is over-represented, the other intervals are under-represented. This statistically confirms the existence of the discontinuities that emerged in the graphical analysis. 


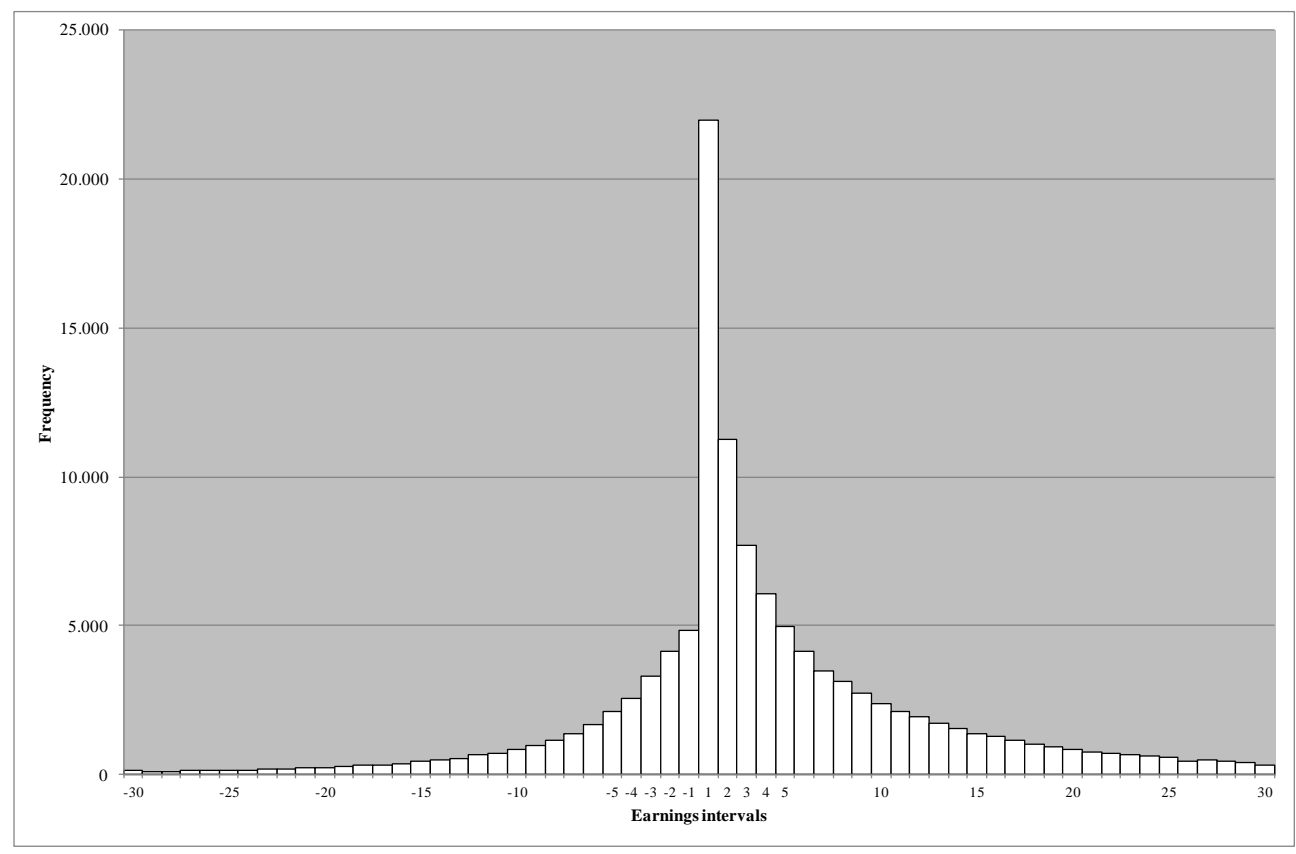

Figure 1. Frequency Distribution of Earnings

The interval amplitude is 0.005. So, the interval that is marked " 1 " is the first positive interval to the right of zero [0; 0.005), the interval that is marked "2" is the second positive interval to the right of zero [0.005; 0.01), and so on. Conversely, the interval that is marked "- 1 " is the first negative interval to the left of zero [-0.005;0), the interval that is marked "-2" is the second negative interval to the left of zero [-0.01; -0.005), and so on. Intervals are closed at the lower limit and open at the higher limit, meaning that each of them includes the lower limit and excludes the upper limit, as marked by the use of square and round brackets respectively. The figure is truncated. It shows only the first thirty intervals of positive earnings (to the right of zero, from 1 to 30) and the first thirty intervals of negative earnings (to the left of zero, from -1 to -30). The figure shows 115860 observations, corresponding to $94 \%$ of the overall sample (123 176 observations).

Table 2. Statistics $\mathrm{Z}$ referring to frequency distribution of earnings levels

\begin{tabular}{|l|r|r|r|r|r|}
\hline $\begin{array}{l}\text { Earnings } \\
\text { intervals }\end{array}$ & \multicolumn{1}{c|}{$\mathrm{na}_{\mathrm{i}}$} & \multicolumn{1}{c|}{$\mathrm{ne}_{\mathrm{i}}$} & \multicolumn{1}{c|}{$\sigma_{\mathrm{i}}$} & \multicolumn{1}{c|}{$\mathrm{Z}_{\mathrm{i}}$} & $\begin{array}{c}p \text {-value } \\
\text { (two tiled) }\end{array}$ \\
\hline-1 & 4848 & 13058 & 96.10 & -85.43 & 0.00000 \\
\hline 1 & 21961 & 8058 & 141.24 & 98.44 & 0.00000 \\
\hline 2 & 11267 & 14821 & 121.87 & -29.16 & 0.00000 \\
\hline 3 & 7681 & 8665 & 102.63 & -9.58 & 0.00000 \\
\hline 4 & 6062 & 6319 & 91.51 & -2.80 & 0.05110 \\
\hline
\end{tabular}

The table reports the values of the statistics $\mathrm{Z}$ only for the intervals for which the difference between the actual and the expected observations appears statistically significant at least at a level of $10 \%$.

The existence of discontinuities in the frequency distribution of earnings is consistent with the practice of earnings management (Burgstahler and Dichev, 1997; Degeorge et al., 1999).

Companies with slightly negative earnings manage them to avoid losses. In fact, there emerges a discontinuity between interval -1 and interval 1 , which is consistent with the presence of earnings management to avoid losses (e.g. Burgstahler and Dichev, 1997; 


\section{Ml Macrothink}

International Journal of Accounting and Financial Reporting

Degeorge et al., 1999). Thus, Hypothesis 1 is confirmed. These findings are consistent with those of previous studies which have found that earnings management to avoid losses is a phenomenon which has great relevance and is widely popular among companies of all countries and categories (e.g. Burgstahler et al., 2006; Coppens and Peek, 2005).

Companies with positive earnings manage them to minimize earnings. In fact, there emerges a discontinuity between interval 1 and intervals 2, 3 and 4, which is consistent with the presence of earnings management to minimize earnings (e.g. Marques et al., 2011; Poli, 2013). Thus, Hypothesis 2 is confirmed. These findings are consistent with those of previous studies which have found that earnings management to minimize companies is a phenomenon which has great relevance and is widely popular among companies of countries like Italy, where there is a close alignment between accounting and tax systems (Marques et al., 2011; Poli, 2013).

The fact that intervals -1 , on the one hand, and intervals 2,3 and 4 , on the other hand, are significantly under-represented, while interval 1 is significantly over-represented means that the latter interval attracts the observations of the former intervals. As a result, companies tend to report slightly positive earnings.

According to previous studies (e.g. Coppens and Peek, 2005; Marques et al., 2011), the presence of fiscal incentives appears to be the best explanation for the earnings management practices found. Fiscal incentives encourage companies to avoid losses to decrease the probability of tax audits and to minimize earnings to minimize tax payments (e.g. Burgstahler et al., 2006; Coppens and Peek, 2005; Herrmann and Inoue, 1996; Marques et al., 2011; Poli, 2013).

Figure 2 shows the frequency distribution of earnings changes of the small-sized Italian companies included in the sample. It presents a trend that is convex both to the left and to the right of zero, a peak of observations in interval 1 , a discontinuity to the left of interval -1 and a discontinuity to the right of interval 1 .

Table 3 shows that there is a statistically significant difference between actual and expected observations in eight earnings change intervals $(-4,-3,-2,-1,1,2,3$ and 4). Intervals -1 and 1 are over-represented, the other intervals are under-represented. This statistically confirms the existence of the discontinuities that emerged in the graphical analysis. 


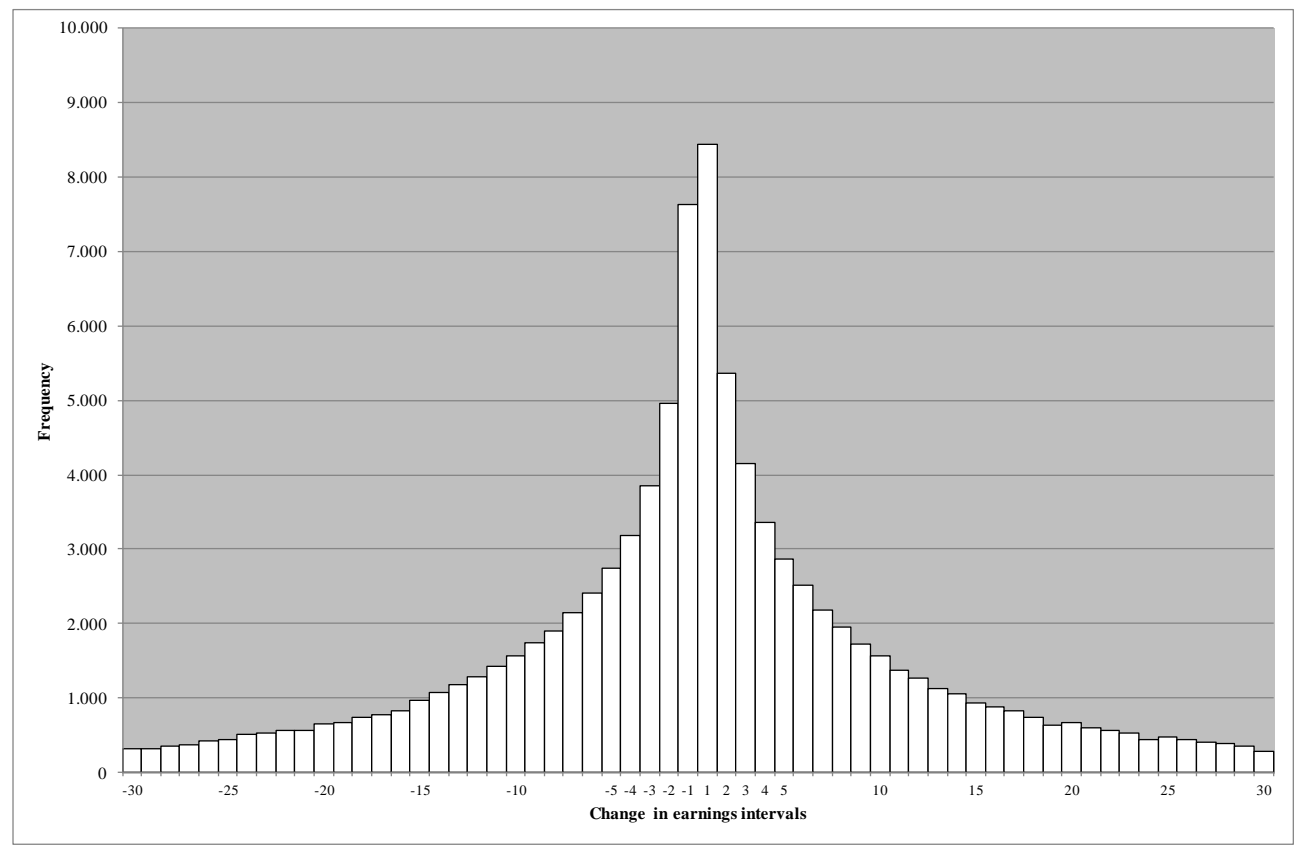

Figure 2. Frequency Distribution of Earnings Changes

The interval amplitude is 0.0025. So, the interval that is marked " 1 " is the first positive interval to the right of zero [0; 0.0025), the interval that is marked "2" is the second positive interval to the right of zero [0.0025; 0.005), and so on. Conversely, the interval that is marked "-1" is the first negative interval to the left of zero [-0.0025; 0), the interval that is marked " -2 " is the second negative interval to the left of zero [-0.005; -0.0025), and so on. Intervals are closed at the lower limit and open at the higher limit, meaning that each of them includes the lower limit and excludes the upper limit, as marked by the use of square and round brackets respectively. The figure is truncated. It shows only the first thirty intervals of positive earnings changes (to the right of zero, from 1 to 30) and the first thirty intervals of negative earnings changes (to the left of zero, from -1 to -30). The figure shows 94254 observations, corresponding to 87\% of the overall sample (107 779 observations).

Table 3. Statistics $\mathrm{Z}$ referring to frequency distribution of earnings change levels

\begin{tabular}{|l|r|r|r|r|r|}
\hline $\begin{array}{l}\text { Earnings } \\
\text { intervals }\end{array}$ & \multicolumn{1}{c|}{$\mathrm{na}_{\mathrm{i}}$} & \multicolumn{1}{c|}{$\mathrm{ne}_{\mathrm{i}}$} & \multicolumn{1}{c|}{$\sigma_{\mathrm{i}}$} & \multicolumn{1}{c|}{$\mathrm{Z}_{\mathrm{i}}$} & $\begin{array}{c}p \text {-value } \\
\text { (two tiled) }\end{array}$ \\
\hline-4 & 3180 & 3307 & 67,83 & -1.86 & 0.06289 \\
\hline-3 & 3860 & 4072 & 74,49 & -2.85 & 0.00437 \\
\hline-2 & 4964 & 5745 & 84,85 & -9.20 & 0.00000 \\
\hline-1 & 7629 & 6698 & 99,20 & 9.39 & 0.00000 \\
\hline 1 & 8431 & 6494 & 102,12 & 18.97 & 0.00000 \\
\hline 2 & 5358 & 6293 & 88,04 & -10.62 & 0.00000 \\
\hline 3 & 4155 & 4358 & 77,03 & -2.64 & 0.00829 \\
\hline 4 & 3358 & 3515 & 69,68 & -2.25 & 0.02445 \\
\hline
\end{tabular}

The table reports the values of the statistics $\mathrm{Z}$ only for the intervals for which the difference between the actual and the expected observations appears statistically significant at least at a level of $10 \%$.

The existence of discontinuities in the frequency distribution of earnings changes is 
consistent with the practice of earnings management (Burgstahler and Dichev, 1997; Degeorge et al., 1999).

Companies do not manage earnings to avoid earnings decreases. In fact, no discontinuity emerges between interval -1 and interval 1 (Burgstahler and Dichev, 1997; Degeorge et al., 1999). Thus, Hypothesis 3 is confirmed. These findings are consistent with those of previous studies which have found that earnings management to avoid earnings decreases is an earnings management practice which has little relevance among private companies (e. g. Coppens and Peek, 2005).

Companies manage earnings to minimize earnings changes. In fact, there emerges a discontinuity between interval -1 and intervals $-2,-3$ and -4 , on the one hand, and a discontinuity between interval 1 and intervals 2,3 and 4 , on the other hand, which are consistent with the presence of earnings management to minimize earnings changes (e.g. Coppens and Peek, 2005). Thus, Hypothesis 4 is confirmed. These findings are consistent with those of previous studies which have found that earnings management to avoid large changes in earnings compared to those of the previous year is a phenomenon which has great relevance and is widely popular among companies of the countries like Italy, where there is a close alignment between accounting and tax systems (e.g. Coppens and Peek, 2005).

The fact that intervals $-4,-3,-2$, on the one hand, and intervals 2,3 and 4 , on the other hand, are significantly under-represented, while intervals -1 and 1 are significantly over-represented means that the latter intervals attract the observations of the former intervals. As a result, companies tend to report smooth earnings.

According to previous studies (e.g. Coppens and Peek, 2005), the presence of fiscal incentives appears to be the best explanation also for the evidence of earnings management practices, for the same reasons pointed out above.

\subsection{Further analysis}

We are interested in verifying whether there exists an association between the two types of earnings management practices that were brought to light in the previous subsection, namely those to report minimal earnings and minimal earnings changes.

To do so, we use the phi-coefficient $(\varphi)$ which is a measure of the degree of association between two binary variables (e.g. Sheskin, 2011).

Given a $2 \mathrm{X} 2$ contingency table as follows:

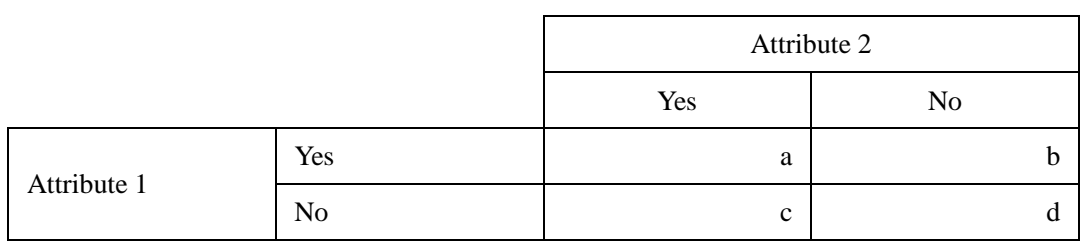

where: Yes and No respectively correspond to the presence or absence of the specific attribute with reference to an observation; $a, b, c$ and d represent the frequencies of observations; 


\section{Macrothink}

the phi-coefficient is determined as follows:

$\varphi=\frac{a d-b c}{\sqrt{(a+b)(c+d)(a+c)(b+d)}}$

The phi-coefficient ranges from 1 to -1 : 1 corresponds to the presence of a full positive correlation; -1 corresponds to the presence of the full negative correlation; 0 corresponds to the absence of correlation.

Since there exists a relationship between the phi-coefficient and the chi-square $\left(\chi^{2}\right)$ as follows:

$$
\varphi^{2}=\frac{X^{2}}{N}
$$

or

$$
\chi^{2}=\mathrm{N} \varphi^{2}
$$

where $\mathrm{N}$ is the overall number of observations $(\mathrm{a}+\mathrm{b}+\mathrm{c}+\mathrm{d})$,

the statistical significance of the phi-coefficient may be tested by determining the value of the chi-square as in (6) and testing it in the usual way.

To calculate the phi-coefficient, we assume that the two earnings management practices that emerged in the previous subsection are the two attributes. Specifically, the practice of reporting minimal earnings is attribute 1 and the practice of achieving minimal earnings changes is attribute 2 . With reference to the first attribute, it is present (Yes) if the observation falls in interval 1, it is absent (No) if the observation falls in the other intervals. With reference to the second attribute, it is present (Yes) if the observation falls in intervals -1 or 1 , it is absent (No) if the observation falls in the other intervals. Since the number of observations is not equal for the two attributes, for the reasons pointed out above, the observations related to 2004 are removed from the first attribute. As a result, the overall number of observations is 107 779. Table 4 shows the frequencies of the two attributes.

Table 4 . The $2 \mathrm{X} 2$ contingency table

\begin{tabular}{|l|l|r|r|r|}
\cline { 3 - 4 } \multicolumn{2}{c|}{} & \multicolumn{2}{c|}{ Earnings change intervals } & \multicolumn{1}{c|}{} \\
\cline { 3 - 5 } \multicolumn{2}{c|}{} & Intervals -1 and 1 & \multicolumn{1}{c|}{ Others } & \multicolumn{2}{c|}{ Total } \\
\hline \multirow{3}{*}{ Earnings intervals } & Interval 1 & 7702 & 11480 & 19182 \\
\cline { 2 - 5 } & Others & 8359 & 80238 & 88597 \\
\hline & Total & 16061 & 91718 & 107779 \\
\cline { 2 - 5 } & &
\end{tabular}

The phi-coefficient, calculated as in (4), is 0.32993. This value reveals that there exists a weak positive association between the two earnings management practices.

The corresponding value of the chi-square, calculated as in (6), is 11732.43 . It exceeds the 


\section{MInstitute Mach $^{m}$}

International Journal of Accounting and Financial Reporting

ISSN 2162-3082

2013, Vol. 3, No. 2

values of 6.63, 3.84 and 2.71 (determined for one degree of freedom) which correspond to a level of significance at $1 \%, 5 \%$ and $10 \%$, respectively. Therefore, we conclude that the null hypothesis of no association between the two earnings management practices is rejected and that the value of the phi-coefficient is statistically significant.

\section{Conclusion}

Adopting the earnings distribution approach, we have found that small-sized Italian companies are likely to manage earnings to report minimal earnings and minimal earnings changes. The first phenomenon is more pervasive than the second one. The two phenomena are positively associated, but the degree of association is weak.

According to previous studies, the presence of fiscal incentives appears to be the best explanation for the two earnings management practices.

The main implication of our findings is that the earnings of small-sized Italian companies are not unconditionally informative regarding their performance. In other words, they are of poor quality. As a result, they should be interpreted with caution by those who use financial statement information.

Our study mainly enriches the literature on earnings management in two ways. Firstly, it provides new evidence on the earnings management practiced by small-sized companies, a topic which is very little explored in literature. Secondly, it provides additional evidence on the earnings management practices undertaken in the Italian setting, as well as in countries which are characterized by a code law system and a close alignment between accounting and tax systems. Compared to Poli (2013), who explored the earnings management practices of larger Italian companies, our study has found that earnings management practices appears to be more pervasive among Italian companies of a smaller size.

The limitations of our study are the same as those generally described in the studies that have explored earnings management practices through the earnings management approach. Dechow et al. (2010, p. 351), for example, have revealed that "In addition to statistical validity issues, evidence that kinks represent opportunistic earnings management is mixed, with credible alternative explanations including non-accounting issues. It is difficult to distinguish firms that are at kinks by chance versus those that have manipulated their way into the benchmark bins". This suggests that caution should be used to interpret our findings.

The adoption of the earnings distribution approach allows us to show neither the magnitude of earnings management practices nor the specific methods used to practice earnings management (e.g. Healy and Wahlen, 1999; Yu et al., 2006). Therefore, further studies are required to gain a full understanding of the earnings management practices of small-sized Italian companies.

\section{References}

Baber, V., \& Kang, S. (2002). The impact of split adjusting and rounding on analysts' forecast error calculations. Accounting Horizons, 16 (4), 277-289.

Beatty, A. L., Ke, B., \& Petroni, K. R. (2002). Earnings management to avoid earnings 
declines across publicly and privately held banks. The Accounting Review, 77 (3), 547-570.

Beaver, W. H., McNichols, M. F., \& Nelson, K. K. (2007). An alternative interpretation of the discontinuity in earnings distributions. Review of Accounting Studies, 12 (4), 525-556.

Brown, L. D., \& Caylor, M. L. (2005). A temporal analysis of earnings management thresholds: propensities and valuation consequences. Accounting Review, 80 (2), 423-440.

Burgstahler, D. C., \& Dichev, I. (1997). Earnings management to avoid earnings decreases and losses. Journal of Accounting and Economics, 24 (1), 99-126.

Burgstahler, D. C., Hail, L., \& Leuz, C. (2006). The importance of reporting incentives: earnings management in European private and public firms. The Accounting Review, 81 (5), 983-1016.

Collins, D. W., Pincus, M., \& Xie, H. (1999). Equity valuation and negative earnings: the role of book value of equity. The Accounting Review, 74 (1), 29-61.

Coppens, L., \& Peek, E. (2005). An analysis of earnings management by European private firms. Journal of International Accounting, Auditing and Taxation, 14 (1), 1-17.

Daske, H., Gebhardt, G., \& McLeay, S. (2006). The distribution of earning relative to targets in the European Union. Accounting \& Business Research, 36 (3), 137-168.

Dechow, P. M., and Skinner, D. J. (2000). Earnings management: reconciling the views of accounting academics, practitioners and regulators. Accounting Horizons, 14 (2), 235-250.

Dechow, P. M., Ge, W., \& Schrand, C. (2010). Understanding earnings quality: a review of the proxies, their determinants and their consequences. Journal of Accounting and Economics, $50(2-3), 344-401$.

Dechow, P. M., Richardson, S. A., \& Tuna, I. (2003). Why are earnings kinky? An examination of the earnings management explanation. Review of Accounting Studies, 8 (2/3), 355-384.

Degeorge, F., Patel, J., \& Zeckhauser, R. (1999). Earnings management to exceed thresholds. The Journal of Business, 72 (1), 1-33.

Durtschi, C., \& Easton, P. (2005). Earnings management? The shapes of the frequency distributions of earnings metrics are not evidence ipso facto. Journal of Accounting Research, 43 (4), 557-592.

Durtschi, C., \& Easton, P. (2009). Earnings management? Erroneous inferences based on earnings frequency distributions. Journal of Accounting Research, 47 (5), 1249-1281.

Easton, P. (1999). Security returns and the value relevance of accounting data. Accounting Horizons, 13 (4), 399-412.

Garrod, N., Ratej Pirkovic, S., \& Valentincic, A. (2006). Testing for discontinuity or type of distribution. Mathematics and Computers in Simulation, 71 (1), 9-15.

Gore, P., Pope, P., \& Singh, A. (2007). Earnings management and the distribution of earnings relative to targets: UK evidence. Accounting and Business Research, 37 (2), 123-150.

Hall, S. C., Agrawal, V., \& Agrawal, P. (2013). Earnings management and the financial statement analyst. Accounting and Finance Research, 2 (2), 105-111. 


\section{MInstitute Macrothink $_{\text {Int }}$}

International Journal of Accounting and Financial Reporting ISSN 2162-3082

Hamdi, F. M., \& Zarai, M. A. (2012). Earnings management to avoid earnings decreases and losses: empirical evidence from Islamic banking industry. Research Journal of Finance and Accounting, 3 (3), 88-107.

Hayn, C. (1995). The information content of losses. Journal of Accounting and Economics, 20 (2), 125-153.

Healy, P. M., \& Wahlen, J. M. (1990). A review of the earnings management literature and its implications for standard setting. Accounting Horizons, 13 (14), 365-383.

Herrmann, D., \& Inoue, T. (1996). Income smoothing and incentives by operating condition: an empirical test using depreciation changes in Japan. Journal of International Accounting, Auditing and Taxation, 5 (2), 161-177.

Holland D., \& Ramsey, A. (2003). Do Australian companies manage earnings to meet simple earnings benchmarks? Accounting and Finance, 43 (1), 41-62.

Holland, D. (2004). Earnings management: a methodological review of the distribution of reported earnings approach. Available at SSRN: http://ssrn.com/abstract $=525242$ or http://dx.doi.org/10.2139/ssrn.525242.

Jacob, J., \& Jorgensen, B. N. (2007). Earnings management and accounting income aggregation. Journal of Accounting and Economics, 43 (2-3), 369-390.

Kerstein J., \& Rai, A. (2007). Intra-year shifts in the earnings distribution and their implications for earnings management. Journal of Accounting and Economics, 44 (3), 399-419.

Marques, M., Rodrigues, L. L., \& Craig, R. (2011). Earnings management induced by tax planning: the case of Portuguese private firms. Journal of International Accounting, Auditing and Taxation, 20 (2), 83-96.

McNichols, M. F. (2000). Research design issues in earnings management studies. Journal of Accounting and Public Policy, 19 (4), 313-345.

McNichols, M. F. (2003). Discussion of "Why are Earnings Kinky? An examination of the earnings management explanation”. Review of Accounting Studies, 8 (2-3), 385-391.

Mörec, B. (2012), Do small companies have superior financial expertise or are they just managing earnings? International Business \& Economics Research Journal, 11 (12), $1289-1298$.

Phillips, J. D., Pincus, M., Rego, S. O., \& Wan, H. (2004). Decomposing changes in deferred tax assets and liabilities to isolate earnings management activities. Journal of the American Taxation Association, 26 (supplement), 43-66.

Poli, S. (2013), The Italian unlisted companies' earnings management practices: the impacts of fiscal and financial incentives, Research Journal of Finance and Accounting, in press.

Prencipe, A., Bar-Yosef, S., Mazzola, P., \& Pozza, L. (2011). Income smoothing in family-controlled companies: evidence from Italy. Corporate Governance: An International Review, 19 (6), 529-546.

Revsine, L., Collins, D., Johnson, W., \& Mittelstaedt, F. (2009). Financial reporting and analysis (4th ed.). New Jersey, NJ: Prentice Hall. 


\section{Macrothink}

International Journal of Accounting and Financial Reporting

ISSN 2162-3082 2013, Vol. 3, No. 2

Schipper, K. (1989). Commentary on earnings management. Accounting Horizons, 3 (4), 91-102.

Scott, D. W. (1992). Multivariate density estimation: theory, practice, and visualization. New York: Wiley.

Sheskin, D. J. (2011). Handbook of parametric and nonparametric statistical procedures (5th ed.). London: Chapman \& Hall - CRC.

Silverman, B.W. (1986). Density estimation for statistics and data analysis. London: Chapman \& Hall.

Sun, L., \& Rath, S. (2010). Earnings management research: a review of contemporary research methods. Global Review of Accounting and Finance, 1 (1), 121-135.

Verbruggen, S., Christaens, J., \& Milis, K. (2008). Earnings management: a literature review [Research paper].

URL https://lirias.hubrussel.be/handle/123456789/2222.

Yu, Q., Du, B., \& Sun, Q. (2006). Earnings management at rights issues thresholds Evidence from China. Journal of Banking \& Finance, 30 (12), 3453-3468.

\section{Copyright Disclaimer}

Copyright reserved by the author(s).

This article is an open-access article distributed under the terms and conditions of the Creative Commons Attribution license (http://creativecommons.org/licenses/by/3.0/). 